\title{
Mikroplastika - potencijalni rizik za sigurnost hrane
} morskog podrijetla

\author{
T. Bogdanović, J. Pleadin, S. Petričević, M. Brkljača, I. Listeš i E. Listeš*
}

\section{Sažetak}

Mikroplastika (MP) je prepoznata kao okolišni kontaminant višestrukih opasnosti na temelju fizičkih učinaka zbog veličine čestica, oblika i koncentracije te kemijskih učinaka povezanih s opasnim kemikalijama. Sve je više dokaza o prisutnosti MP u hrani, a posljednjih godina se eksponencijalno povećava i broj publikacija o njezinoj prisutnosti $\mathrm{u}$ hrani morskog podrijetla. Međutim, analitičke metode detekcije u hrani morskog podrijetla su unatoč dostupnosti širokog spektra instrumentalnih tehnika za izolaciju i određivanje njezinih fizikalnih svojstava ograničene. Potpuni analitički postupak donosi podatke o kemijskom sastavu i morfološkoj strukturi čestica, ali niti jedna instrumentalna tehnika ne udovoljava svim zahtjevima analize MP. Primjena većeg raspona komplementarnih analitičkih metodologija u pogledu otkrivanja i identifikacije ispunjava zahtjevnost analize ovog okolišnog kontaminanta. Pojava i vrsta unesene MP, kao i njezini zdravstveni učinci koji se trenutno ispituju, uključuju biološke, kemijske i fizičke vrste utjecaja. U svrhu procjene utjecaja MP iz hrane morskog podrijetla na ljudsko zdravlje prvo se mora kvantificirati izloženost, a zatim utvrditi je li ta izloženost dovoljno velika da bi izazvala posljedice sa štetnim učincima. Izloženost ljudi hrani morskog podrijetla izaziva zabrinutosti zbog njezine kontinuirane akumulacije u okolišu. Cilj ovog rada je prikazati dosadašnje spoznaje o prisutnosti MP u hrani morskog podrijetla: školjkašima, ribi i rakovima kao glavnim izvorima. Posebno se analiziraju postojeći analitički pristupi ekstrakcije i instrumentalnog određivanja koncentracije, oblika i vrste materijala MP u zahtjevnim biološkim uzorcima. Istaknuta je potreba daljnje istraživačke aktivnosti o ovom kontaminantu, kao i potreba za stvaranje baze podataka koja je neophodna za uspostavu zakonodavstva u području hrane.

Ključne riječi: mikroplastika, hrana morskog podrijetla, pojaonost, procjena izloženosti

Dr. sc. Tanja BOGDANOVIĆ, dipl. ing. biotehnol., viša znanstvena suradnica, Hrvatski veterinarski institut, Veterinarski zavod Split, Split, Hrvatska; dr. sc. Jelka PLEADIN, dipl. ing. biotehnol., znanstvena savjetnica u trajnom zvanju, redovita profesorica, Hrvatski veterinarski institut, Zagreb, Hrvatska; dr. sc. Sandra PETRIČEVIĆ, dipl. ing. kem. tehnol., poslijedoktorandica, Hrvatski veterinarski institut, Veterinarski zavod Split, Split, Hrvatska; dr. sc. Mia BRKLJAČA, dipl. ing. agr., Cromaris d.d., Zadar, Hrvatska; dr. sc. Irena LISTEŠ, dr. med. vet., znanstvena suradnica, dr. sc. Eddy LISTEŠ*, dr. vet. med., znanstveni savjetnik, (dopisni autor, e-mail: e.listes.vzs@veinst.hr), Hrvatski veterinarski institut, Veterinarski zavod Split, Split, Hrvatska 


\section{Uvod}

Proizvodi od plastike proizvode se sve bržim tempom, a budući da su teško razgradljivi te uz djelovanje biotičkih i abiotičkih čimbenika podložni degradaciji na sitnije čestice i akumulaciji u okolišu, predstavljaju jedno od najznačajnijih suvremenih ekoloških pitanja. Plastika je vrlo praktičan polimerni materijal koji je dugotrajan, otporan na propadanje, inertan i jednostavan za oblikovanje, s malim troškom proizvodnje. To je organski polimer koji potječe iz nafte, a uključuje polietilen (PE), polipropilen (PP), polivinilklorid (PVC) i poliester (AU), od kojih su PE i PP standardni, i drže i prvu i drugu poziciju na svjetskom tržištu. Nakon njih slijedi polietilen tereftalat (PET) (Leng i sur., 2018.) s oko $18 \%$ globalne svjetske proizvodnje.

Pod izrazom mikroplastika (MP) podrazumijeva se vrlo širok skup čestica koje $u$ procjeni rizika zbog njihove iznimne raznolikosti (veličina, oblik, topljivost, sastav polimera, adsorbirane kemikalije, biološki materijal, itd.). predstavljaju jedinstvene izazove. Sastoji se od složenog niza polimera s ponovljenim monomerima koji čine temelj i bazu polimera. Temeljna razlika između polimera je struktura osnovnog lanca koja određuje fizikalno-kemijska svojstva plastike (Rochman i sur., 2019.). Bioraspoloživost je postotak ukupne količine čestica dostupnih za apsorpciju od strane organizma u okolišu (Vallero, 2016.). Na bioraspoloživost MP mogu utjecati različiti čimbenici od kojih su brojnost i svojstva plastike najznačajniji. Raspadanjem i fragmentacijom plastičnih čestica, dostupnost MP koja vrstama postaje biološki dostupna s vremenom raste (Botterell i sur., 2019.).

Svi izvori MP $u$ hrani za ljude i životinje trenutno su nepoznati. Pretpostavlja se da je njezin ulaz u prehrambeni lanac putem plastičnog otpada koji se u matricama okoliša (vode i zraka) razgrađuje. Prijenos MP kroz prehrambeni lanac u vodenom okolišu djelomično je razjašnjen, dok je dinamika u kopnenim prehrambenim lancima uglavnom nepoznata. Pojavnost njezinih čestica utvrđena je u probavnom sustavu vodenih organizama, uključujući i vrste koje se koriste za prehranu ljudi (Hantoro i sur., 2019.). Zbog moguće translokacije ovih čestica iz crijeva $u$ druga tkiva, MP bi mogla biti prisutna i $\mathrm{u}$ jestivim dijelovima hrane morskog podrijetla. Slijedom mogućnosti ispiranja i nakupljanja aditiva ili postojanih organskih onečiščujućih tvari adsorbiranih na čestice $u$ okolišu moguće je djelovanje MP na hranu morskog podrijetla pa i zdravlje ljudi.' Međutim, osim procjene toksičnosti, podatci o pojavnosti MP $\mathrm{u}$ jestivim dijelovima hrane morskog podrijetla važan su preduvjet za procjenu rizika.

Osim malog broja studija koje analiziraju MP u jestivom dijelu hrane morskog podrijetla, trenutno ne postoji standardizirana metoda za njezin dokaz $u$ jestivim dijelovima morskih organizama. Plastično onečišćenje kompleksno je kvantificirati u biološkim tkivima i otpadnim vodama (Nguyen i sur., 2019.). Analitičke protokole treba optimizirati da bi se povećala iskoristivost metode, smanjio potencijal zagađenja i izbjeglo uništavanje plastičnih polimera mikroplastike tijekom obrade uzoraka (Hermabessiere i sur., 2018., Dehaut i sur., 2019.). Izoliranu plastiku iz okolišnog uzorka neophodno je vizualno i kemijski identificirati (Süssmann i sur., 2021.). Uz postojeće tehnike, MP i nanoplastiku (NP) je teško okarakterizirati, ali i otkriti. Njihova mala masa i mala veličina pružaju ograničen signal za vizualne, vibracijsko-spektroskopske i analize uz primjenu masene spektrometrije (Nguyen i sur., 2019.). Svaka od ovih tehnika uključuje kompromis u propusnosti, prostornoj rezoluciji i 
osjetljivosti. Za točnu identifikaciju i potpunu kvantifikaciju u uzorcima okoliša vjerojatno će biti potrebno više analitičkih tehnika.

$\mathrm{U}$ ovom je radu razmatrana MP kao okolišni kontaminant i potencijalni rizik za sigurnost hrane morskog podrijetla. Analiza i odvajanje najmanjih frakcija MP prikazani su za analitički najzahtjevnije uzorke biološkog materijala. Sumirane su dosadašnje spoznaje o nakupljanju plastičnog otpada svih trofičkih razina morskog prehrambenog lanca, odnosno ribama, školjkama i rakovima kao glavnim izvorima hrane morskog podrijetla. Sažete su i regulatorne potrebe te daljnji izazovi u cilju realizacije budućih istraživačkih aktivnosti i doprinosa procjeni rizika i karakterizaciji opasnosti ovog okolišnog kontaminanta.

\section{Definicije i karakterizacija}

Sintetički polimerni materijali su organski materijali (ugljikovodici) velike molekularne mase (makromolekule ili polimerni lanac) nastali tijekom procesa polimerizacije sintezom monomera (slika 1.). Biorazgradivi polimerni materijali poliaktid (PLA) i polikaprolalton, (PCL) i drugi-polimeri, kao što su polipropilen $(\mathrm{PP})$, polietilen niske gustoće (PE-LD), polietilentereftalat (PET), poliamid (PA), politetrafluoretilen (PTFE), fenolformaldehidna smola (PF), epoksid/ epoksidna smola ili plastika (EP), etilen/ propilen/dienski kaučuk (EPDM) sintetički su polimeri. MP se sastoji od složenog niza polimera $\mathrm{s}$ ponovljenim monomerima koji čine temelj polimera. Temeljna razlika između polimera je osnovna struktura koja određuje

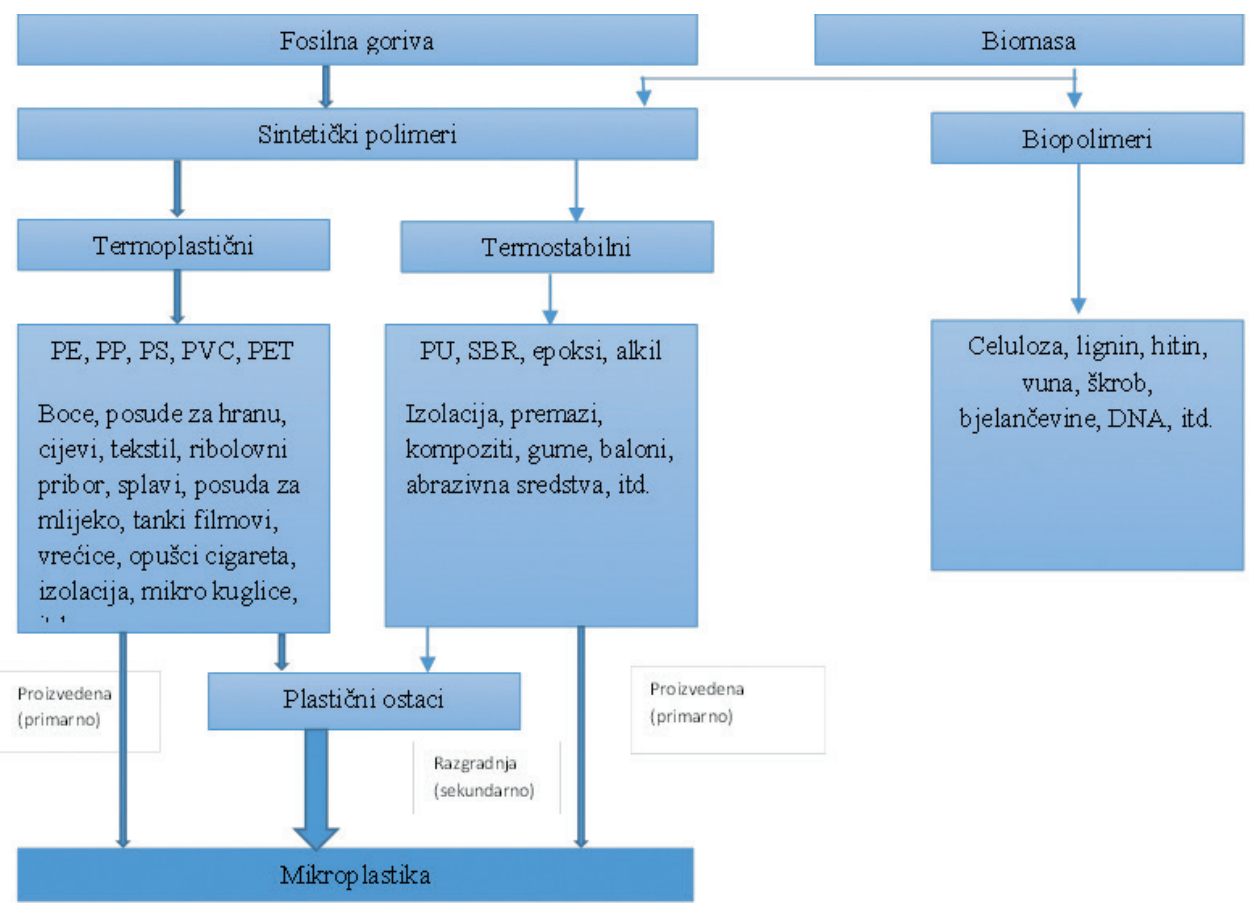

Slika 1. Prikaz odnosa između izvora primarnih materijala, sintetičkih i prirodnih polimera, termoplastike i termoreaktivne plastike i njihove primjene (Izvor: GESAMP, 2015.)

PE-polietilen, PP-polipropilen, PS-polistiren, PVC-polivinil klorid, PET-poli(etilen-tereftalat), PUpoliuretan, SBR-stiren-butadienski kaučuk 
fizikalno-kemijska svojstva polimernih materijala (Rochman i sur., 2019.). Prema izvoru stvaranja MP se dijeli na primarnu i sekundarnu mikroplastiku. Primarna se mikroplastika može naći u proizvodima za osobnu njegu (mikro kuglice), u obliku plastičnih peleta koji se koriste $\mathrm{u}$ industrijskoj proizvodnji ili plastičnih vlakana koja se koriste u sintetičkom tekstilu. Ove čestice izravno ulaze u prirodne ekosustave iz različitih izvora. Sekundarna MP nastaje raspadom većih čestica polimernih materijala $\mathrm{u}$ okolišu pod utjecajem prirodnih i vremenskih utjecaja. Utvrđeno je da se obje vrste akumuliraju i opstaju u prirodnim vodenim ekosustavima, a čestice sekundarne MP mogu se dalje razgrađivati do NP.

Za sada ne postoji međunarodno prihvaćena definicija MP. Prema definiciji Europske agencije za kemikalije (ECHA), MP predstavlja materijal koji se sastoji od čvrstih čestica koje sadrže polimer u koji su možda dodani i aditivi ili druge tvari i gdje je $\geq 1 \%$ masene koncentracije raspona veličina od $1 \mathrm{~nm} \leq \mathrm{x} \leq 5 \mathrm{~mm}$ ili kod oblika vlakna raspona duljina od $3 \mathrm{~nm} \leq \mathrm{x} \leq 15 \mathrm{~mm}$ i omjera duljine i promjera $>3$. Polimeri, koji se pojavljuju u prirodi, a koji nisu kemijski modificirani (osim hidrolizom) isključeni su, kao i polimeri koji su (bio) razgradivi (ECHA, 2019.). MP i NP su slične veličine kao i mnogi dijelovi bioloških organizama te ih postaje sve teže i skuplje analizirati sa smanjivanjem veličine. Prisutnost plastičnog materijala $\mathrm{u}$ hrani vezana je uz termoplastične polimere, odnosno PE, PP, PS i PET koji obuhvaćaju većinu MP koja se nalazi u hrani (Karami i sur., 2017., Fang i sur., 2019., Akoueson i sur., 2020.). U svim namirnicama PE, PP, PS i PET (uključujući poliestere) čine više od $50 \%$ MP. Utvrđeno je da je celofan dominantan u kuhinjskoj (morskoj) soli (Renzi i sur., 2019.), ribi i školjkama (Jaaben i sur., 2017.).
Prema obliku čestica MP razlikujemo vlakna, fragmente, pelete ili filmove (Lusher i sur., 2013., Cau i sur., 2019.). Vlakna su kritična jer se smatra da pri nižim dozama od čestica oblika kugle izazivaju toksične učinke (Qiao i sur., 2019.). Prisutnost vlakana, uključujući čestice klasificirane kao "vlakna" svojstvena je mnogim prehrambenim proizvodima (Lusher i sur., 2013., Li i sur., 2018., Waddell i sur., 2020.). U riba je izražena samo MP izolirana iz jestivog tkiva. Postotak vlakana u izoliranoj MP u raznim prehrambenim proizvodima bio je veći od $50 \%$. Međutim, mali udio (< $20 \%$ ) vlakana identificiran je u jezerskim solima (Kim i sur., 2018.), jestivim tkivima riba (Rochman i sur., 2015.), dagnjama (Phuong i sur., 2018.), škampima (Cau i sur., 2019.) i sušenoj ribi (Karami i sur., 2017.). Ova varijacija u postotku vlakana može se pripisati različitim izvorima $\mathrm{MP}$, razlikama u matricama hrane i primjeni različitih analitičkih metoda. Ovisno o dodatku spojeva punila ili prisutnosti sporednih spojeva (npr. nečistoće koje proizlaze iz proizvodnih procesa) sastav MP može varirati.

\section{Analitičke metode za ispitivanje MP}

Analiza MP iz okolišnih uzoraka i biološkog materijala sastoji se iz postupaka izolacije, digestije, identifikacije, kemijske karakterizacije i kvantifikacije (Silva i sur., 2018.). Analizom se primarno dobivaju podatci o broju identificiranih čestica, veličini, obliku, boji te u smislu kemijskog sastava, broju i vrsti kemijskih polimera. Ovisno o primijenjenoj tehnici identifikacije i kvantifikacije poželjno je dobiti informacije o aditivima (plastifikatori ili omekšivači, pojačivači, punila, boje, usporavala gorenja, modifikatori) i apsorbiranim štetnim tvarima poliklorirani bifenili (PCB), insekticidi 
kao diklorodifeniltrikloroetan (DDT), policiklički aromatski ugljikovodici (PAH). Svi su navedeni analitički podatci neophodni za određivanje utjecaja na živi svijet, uključujući i ljude. Složenost postupka izolacije ovisi o vrsti uzorka. MP je potrebno prvo izolirati iz uzoraka vode, sedimenata i biološkog materijala da bi se mogla kvantificirati i okarakterizirati. Izdvajanje iz uzoraka vode i sedimenata provodi se redukcijom volumena uzorka - korištenjem mreža tijekom skupljanja ili prosijavanjem ukoliko se radi o krupnijim česticama te njezinim odvajanjem, obično filtriranjem i/ili izdvajanjem na temelju različite gustoće (preporuča se korištenje $\mathrm{NaCl}$ ) (Hegedušić, 2019., Nguyen i sur., 2019.). Filtriranje je najčešći postupak u izdvajanju MP iz uzorka vode. Veličine pora mreže/filtera mogu znatno varirati, od $0,45 \mu \mathrm{m}$ do 55,5 mm. Međutim, male veličine pora također mogu dovesti do brzog zasićenja mreže/filtera organskim i mineralnim tvarima. Postupci određivanja ovog kontaminanta $u$ okolišnim uzorcima sastoje se iz nekoliko faza, koje uključuju: vizualnu identifikaciju - mikroskopska analiza nakon koje slijedi kemijska identifikacija plastičnih polimera te izražavanje ukupne količine MP primjenom vizualne mikroskopske analize i vibracijske spektroskopije (broj čestica MP/g uzorka ili broj čestica MP/jedinici ispitanog biološkog uzorka; primjerice kod određivanja u školjkašima broj čestica MP se može izraziti po jedinici ispitane školjke. Navedenim tehnikama se dobivaju podatci o fizikalno-kemijskim svojstvima; fizička karakterizacija odnosi se uglavnom na raspodjelu veličine MP kao i na procjenu drugih fizikalnih parametara kao što su oblik i boja te kemijska karakterizacija - uglavnom se primjenjuje pri istraživanju sastava $\mathrm{MP}$ te se $\mathrm{u}$ tu svrhu upotrebljavaju različiti uređaji poput Fouriertransform infrared spektrofotometra
(FTIR), Raman spektrofotometra, skenirajućeg elektronskog mikroskopa (SEM) te uređaja za ultra tekućinsku kromatografiju visoke djelotvornosti uz tandemsku masenu spektrometriju (UPLC-MS/MS) (Bogdanović i sur., 2021.) i za plinsku kromatografiju/ masenu spektrometriju (GC/MS).

\section{Metode obrade uzoraka}

Uklanjanje organske tvari je primarni postupak analize MP iz hrane morskog podrijetla, koji ne smije narušiti strukturni ili kemijski integritet polimera. Slično kontaminantima - teškim metalima izolacija čestica MP iz uzoraka hrane nije moguća ekstrakcijom različitim otapalima već potpunom razgradnjom uzorka koja može biti kiselinska, bazna ili enzimska (Raamsdonk i sur., 2020.) (Tabela 1.). Kiselinska ili bazna razgradnja često se uspješno koristi za izolaciju MP iz bioloških tkiva. Dušična kiselina $\left(\mathrm{HNO}_{3}\right)$, kalijev hidroksid $(\mathrm{KOH})$ i vodikov peroksid $\left(\mathrm{H}_{2} \mathrm{O}_{2}\right)$ učinkoviti su i široko se primjenjuju $u$ razgradnji tkiva i smanjenju nepoželjnih ostataka biološkog materijala poput proteinskih i masnih frakcija tkiva. Druge jake kiseline (npr. klorovodična kiselina) i baze (npr. natrijev hidroksid) mogu se koristiti i kao sredstva u razaranju biološkog materijala. Međutim, zavisno o vrsti polimera može doći do razgradnje i oštećenja polimera, osobito pri višim temperaturama $\left(>80^{\circ} \mathrm{C}\right)$, dok su polimeri poput polietilena (PE) i polivinil klorida (PVC) termorezistentni. Enzimi kao proteinaza K, hitinaza, celulaza također se uspješno primjenjuju u razgradnji biološkog materijala, bilo samostalno ili u kombinaciji s lužinama ili kiselinama.

Najnovija znanstvenoistraživačka literatura o MP u hrani morskog podrijetla (Dehaut i sur., 2019., Danopoulos i sur., 2020., Dawson i sur., 2021.) ukazuje na suprotstavljene rezultate o učinkovitosti primjene kemijskih reagensa $u$ razgradnji biološkog materijala kao što 
Tabela 1. Prednosti i nedostatci postupaka izolacije mikroplastike iz biološkog materijala (Izvor: Kwon i sur., 2020.)

\begin{tabular}{|c|c|c|c|}
\hline $\begin{array}{l}\text { Primjena } \\
\text { postupka } \\
\text { izolacije }\end{array}$ & $\begin{array}{l}\text { Vrsta biološkog } \\
\text { materijala }\end{array}$ & Prednosti & Nedostatci \\
\hline Ispiranje & & & $\begin{array}{l}\text { Potencijalna pojavnost } \\
\text { lažno pozitivnih uzoraka, } \\
\text { često zahtijeva bojanje }\end{array}$ \\
\hline \multicolumn{4}{|c|}{ Oksidativna razgradnja } \\
\hline $\mathrm{H}_{2} \mathrm{O}_{2}$ & $\begin{array}{l}\text { Riba, školjkaši, } \\
\text { biološki materijal } \\
\text { životinjskog ili } \\
\text { biljnog podrijetla }\end{array}$ & $\begin{array}{l}\text { Smanjeni troškovi i vrijeme } \\
\text { digestije, učinkovit za razaranje } \\
\text { biološkog materijala }\end{array}$ & $\begin{array}{l}\text { Razgradnja polimera PA, } \\
\text { PVC, polimetilmetakrilata } \\
\text { i najlona, promjena boje } \\
\text { polimera PET }\end{array}$ \\
\hline $\begin{array}{l}\text { Fentonov } \\
\text { reagens }\end{array}$ & Morski organizmi & $\begin{array}{l}\text { Poželjan u konzerviranju } \\
\text { čestica mikroplastike; učinkovit } \\
\text { u uklanjanju organskih } \\
\text { komponenti }\end{array}$ & $\begin{array}{l}\text { Mora se testirati i } \\
\text { provjeriti na raznorodnim } \\
\text { biološkim matriksima }\end{array}$ \\
\hline \multicolumn{4}{|c|}{ Lužnata razgradnja } \\
\hline $\mathrm{KOH}$ & $\begin{array}{l}\text { Riba, hrana } \\
\text { morskog podrijetla, } \\
\text { ostali morski } \\
\text { organizmi }\end{array}$ & $\begin{array}{l}\text { Učinkovita u uklanjanju } \\
\text { proteina, ne utječe na vrste } \\
\text { polimera koje su izložene } \\
\text { prethodnoj okolišnoj razgradnji }\end{array}$ & $\begin{array}{l}\text { Organske tvari primjerice: } \\
\text { krakovi lignje, parafin } \\
\text { i palmina mast se } \\
\text { ne razaraju; polimer } \\
\text { celuloza-acetata se razara }\end{array}$ \\
\hline $\mathrm{NaOH}$ & $\begin{array}{l}\text { Hrana morskog } \\
\text { podrijetla, } \\
\text { zooplankton, } \\
\text { kopepodi } \\
\text { (veslonošci, dagnje) }\end{array}$ & $\begin{array}{l}\text { Cjelovita razgradnja mekog } \\
\text { tkiva; dobro iskorištenje PET i } \\
\text { HDPE polimera (>97\%) }\end{array}$ & $\begin{array}{l}\text { Nedostatna zastupljenost } \\
\text { pH-osjetljivih polimera; } \\
\text { djelomična razgradnja } \\
\text { najlona, otapanje } \\
\text { polietilena, žuto obojenje } \\
\text { PVC polimera, gubitak } \\
\text { ponekih poliesterskih } \\
\text { vlakana }\end{array}$ \\
\hline \multicolumn{4}{|c|}{ Kisela razgradnja } \\
\hline $\mathrm{HNO}_{3}$ & $\begin{array}{l}\text { Riba, hrana } \\
\text { morskog podrijetla, } \\
\text { dagnje pjeskulja }\end{array}$ & $\begin{array}{l}\text { Omogućena cjelovita razgradnja } \\
\text { zamrznutog uzorka uz blago } \\
\text { miješanje tijekom } 1 \mathrm{~h}\end{array}$ & $\begin{array}{l}\text { Neudovoljavajući rezultati } \\
\text { cjelovitosti čestica } \\
\text { plastičnog polimera; } \\
\text { opadanje mase čestica } \\
\text { polimera PA-12 otapanje } \\
\text { LDPE, HDPE, PET i } \\
\text { PP polimera; potpuno } \\
\text { razaranje vlakana najlona }\end{array}$ \\
\hline $\mathrm{HCl} / \mathrm{HNO}_{3}$ & Ribe & $\begin{array}{l}\text { Povećanje iskorištenja uz porast } \\
\text { temperature do } 60^{\circ} \mathrm{C}\end{array}$ & $\begin{array}{l}\text { Nedostatno iskorištenje } \\
\text { razaranja biološkog } \\
\text { materijala } \\
(52,5-53,3 \%)\end{array}$ \\
\hline $\mathrm{HClO}_{4}$ & $\begin{array}{l}\text { Tkiva dagnji i } \\
\text { smeđeg škampa }\end{array}$ & $\begin{array}{l}\text { Jača perklorna kiselina reducira } \\
\text { ostatak frakcije masnog tkiva } \\
\text { nakon razaranja; slabiji utjecaj } \\
\text { na degradaciju plastičnog } \\
\text { polimera u odnosu na ostale } \\
\text { razgradnje kiselinama }\end{array}$ & $\begin{array}{l}\text { Narušena cjelovitost } \\
\text { čestica mikroplastike, žuto } \\
\text { obojenje uzoraka }\end{array}$ \\
\hline
\end{tabular}


Tabela 1. (nastavak)

\begin{tabular}{|c|c|c|c|}
\hline $\begin{array}{c}\text { Primjena } \\
\text { postupka } \\
\text { izolacije }\end{array}$ & $\begin{array}{l}\text { Vrsta biološkog } \\
\text { materijala }\end{array}$ & Prednosti & Nedostatci \\
\hline \multicolumn{4}{|c|}{ Enzimska razgradnja } \\
\hline $\begin{array}{l}\text { Korolaza } \\
7089 \\
\text { (bakterijska } \\
\text { proteaza) }\end{array}$ & Dagnje & $\begin{array}{l}\text { Dostatna za razaranje } \\
\text { mekog tkiva uz očuvanje } \\
\text { čestice mikroplastike; visoko } \\
\text { iskorištenje }(93 \pm 10 \%)\end{array}$ & $\begin{array}{l}\text { Neophodna ispitivanja na } \\
\text { različitim vrstama uzoraka }\end{array}$ \\
\hline $\begin{array}{l}\text { Alkalaza } \\
\text { lindustrijska } \\
\text { proteaza) }\end{array}$ & Tkivo plave dagnje & $\begin{array}{l}\text { Visoko iskorištenje digestije } \\
(98,3-99,35 \%) \text { pri niskim } \\
\text { koncentracijama; bez vizualnih } \\
\text { promjena polimera }\end{array}$ & $\begin{array}{l}\text { Potrebna ispitivanja } \\
\text { utjecaja na različitim } \\
\text { vrstama plastičnih } \\
\text { polimera }\end{array}$ \\
\hline Proteinaza-K & $\begin{array}{l}\text { Plankton podrijetlom } \\
\text { iz morske vode, } \\
\text { morski organizmi, } \\
\text { Antarktički kril }\end{array}$ & $\begin{array}{l}\text { Visoka učinkovitost, neoštećene } \\
\text { čestice mikroplastike }\end{array}$ & $\begin{array}{l}\text { Skupa i nedostatna za } \\
\text { razgradnju hitina }\end{array}$ \\
\hline Tripsin & Tkiva dagnji & $\begin{array}{l}\text { Blago razaranje ne utječe na } \\
\text { promjene oblika i boje polimera }\end{array}$ & $\begin{array}{l}\text { Mišić aduktor i opna } \\
\text { plašta su djelomično } \\
\text { razgrađeni }\end{array}$ \\
\hline $\begin{array}{l}\text { Papain/ } \\
\text { kolagenaze }\end{array}$ & Tkiva dagnji & $\begin{array}{l}\text { Bez značajnih promjena na } \\
\text { izložene polimere mikroplastike }\end{array}$ & $\begin{array}{l}\text { Manje iskorištenje } \\
\text { razgradnje od tripsina }\end{array}$ \\
\hline
\end{tabular}

su: vodikov-peroksid, kalijev hidroksid i dušična kiselina. Međutim, bez obzira na vrstu razgradnje prilagođenu kategorijama hrane krajnje je vrijeme da se definiraju i usvoje svi metodološki parametri. Bitno je istaknuti da nije uvijek neophodno dokazati sve polimere i primijeniti najskuplje protokole primjenom enzimskih, oksidativnih, kiselih i lužnatih postupaka razgradnje, već pronaći brze i učinkovite postupke kojima je s prihvatljivim iskorištenjem moguće izolirati najzastupljenije cjelovite čestice ovog vrlo značajnog kontaminanta. Jedno od potencijalnih rješenja omogućuje razgradnja čestica MP primjenom mikrovalnog razaranja dušičnom kiselinom (Bitencourt i sur., 2020.).

\section{Metode identifikacije čestica MP}

Kako je prethodno navedeno, dvije temeljne metode identifikacije MP u hrani su vizualni pregled pod disekcijskim mikroskopom sa ili bez bojenja i apsorpcija ili refleksija IR-a pomoću FT-IR ili Ramanove spektroskopije (tabela 2.). Fourieriova infracrvena spektroskopija (FTIR) i Ramanova spektroskopija su metode vibracijske spektroskopije koje su nedestruktivne, vrlo točne i komplementarne, stvarajući spektar temeljen na interakciji svjetla sa molekulama. FTIR proizvodi infracrveni spektar koji proizlazi iz promjene dipolnog momenta, dok Raman osigurava molekularni spektar otisaka na temelju polarizabilnosti kemijskih veza. Vibracijska je spektroskopija tijekom analize i obrade uzoraka ograničena visokom cijenom, raspoloživošću opreme, vremenom i visokom zahtjevnošću postupaka (Catarino i sur., 2018.).

Metode masene spektrometrije, tehnikama koje uključuju termalno- 
Tabela 2. Prednosti i nedostaci osnovnih metoda karakterizacije mikroplastike (Izvor: Kwon, i sur., 2020.J

\begin{tabular}{|c|c|c|}
\hline $\begin{array}{l}\text { Metode identifikacije } \\
\text { mikroplastike }\end{array}$ & Prednosti & Nedostatci \\
\hline Vizualna analiza & Niski trošak analize; brza analiza & $\begin{array}{l}\text { Moguća detekcija lažno- } \\
\text { pozitivnih uzoraka }\end{array}$ \\
\hline $\begin{array}{c}\text { Skenirajuća elektronska } \\
\text { mikroskopija }\end{array}$ & $\begin{array}{c}\text { Bez ograničenja u odnosu na } \\
\text { veličinu čestica }\end{array}$ & $\begin{array}{l}\text { Moguća detekcija lažno- } \\
\text { pozitivnih uzoraka }\end{array}$ \\
\hline Mikroskopija/FT-IR & $\begin{array}{c}\text { U kombinaciji s vizualnom analizom; } \\
\text { kemijska potvrda polimera; relativno } \\
\text { brzo skeniranje }\end{array}$ & $\begin{array}{l}\text { Ograničenje u odnosu na } \\
\text { veličinu čestica } \sim 20 \mu \mathrm{m}\end{array}$ \\
\hline Mikroskopija/Raman & $\begin{array}{l}\text { U kombinaciji s vizualnom analizom; } \\
\text { kemijska potvrda polimera; relativno } \\
\text { brzo skeniranje; moguća detekcija } \\
\text { do veličine od svega nekoliko } \mu \mathrm{m}\end{array}$ & Vremenski zahtjevna; skupa \\
\hline $\begin{array}{c}\text { Termalna desorpcijska } \\
\text { analiza/GC-MS }\end{array}$ & $\begin{array}{c}\text { Mjerenje mase; jednostavan } \\
\text { postupak }\end{array}$ & $\begin{array}{c}\text { Bez podataka o veličini i } \\
\text { distribuciji; moguće } \\
\text { međudjelovanje s većim } \\
\text { česticama; zahtijeva kalibraciju }\end{array}$ \\
\hline
\end{tabular}

desorpcijsku plinsku kromatografijumasenu spektrometriju (TDS-GC-MS) i pirolitičku plinsku kromatografijumasenu spektrometriju (PYR-GC-MS), zahtijevaju skupnu analizu uzorka. U odnosu na metode vibracijske spektroskopije karakterizira ih potencijalno povećana osjetljivost, što može omogućiti otkrivanje NP, ali i ispitivanja u različitim tkivima organizama. Signal detekcije ovisi o ukupnoj analiziranoj masi. Ove su metode prikladne za kvalitativnu identifikaciju smjese plastičnih čestica. TDS-GC-MS zahtijeva postavljanje uzorka na termogravimetrijsku vagu (Dümichen i sur., 2017.) i zagrijavanje na temperaturi do 1000 ${ }^{\circ} \mathrm{C}$. Degradirane sastavnice izvornog uzorka se adsorbiraju na krutoj fazi, koja se prebacuje u jedinicu za toplinsku desorpciju, gdje se uz povećanje temperature desorbirane komponente razdvajaju na kromatografskoj koloni plinskog kromatografa i analiziraju masenim spektrometrom. Py-GCMS uključuje razgradnju uzorka pri visokim temperaturama, razdvajanje produkata plinskom kromatografijom i detekciju masenim spektrometrom. Iako su metode termalne desorpcije plinske kromatografije sa spektrometrijom masa destruktivne metode, bitne su zbog mogućnosti izražavanja mase čestica MP u okolišnim uzorcima (Ribeiro i sur., 2020.) i istovremene detekcije širokog spektra aditiva polimernih materijala.

Eksperimentalne metode za izolaciju i identifikaciju MP u hrani još uvijek trebaju poboljšanje u smislu povećanja iskorištenja primijenjene metodologije u različitim matricama hrane i kvantitativne usporedbe provedenih znanstvenih ispitivanja. Dva postojeća pristupa - brojenje MP s mikroskopijom i destruktivna pirolitička, odnosno termodesorpcijska mikroplastična detekcija, s termičkom analizom međusobno se nadopunjavaju. Osim toga, onečišćenje i dekontaminacija MP tijekom prerade hrane i kuhanja važni su, jer izloženost ljudi ovom kontaminantu ponajprije dolazi od konzumiranih finalnih proizvoda, a ne od njihovih sastojaka. 


\section{Od plastike do MP u morskom okolišu}

MP je sveprisutan problem među svim morskim vrstama neovisno o veličini, trofičkoj razini, prehrambenim navikama, udaljenosti od obale i staništu. Pronađena je gotovo $u$ svim dijelovima morskog okoliša, od najudaljenijih područja dubokog mora pa sve do početnih razvojnih faza morskih organizama (ličinke i manje ribe) (Bajt, 2021.). Pojava unesenih čestica MP u morskom ekosustavu i vodenim organizmima, kao i njihova raspodjela duž trofičkih razina morskog prehrambenog lanca, uz identifikaciju prikladnih indikatorskih vrsta $\mathrm{u}$ hrani morskog podrijetla, prioritet su većine istraživanja tijekom zadnjeg desetljeća (Phuong i sur., 2018., Fang i sur., 2019., Mercogliano i sur., 2020.). Navedeno ne čudi uzimajući u obzir Okvirnu direktivu o morskoj strategiji (Direktiva (EZ) br. 56/2008) koja u cilju postizanja dobrog stanja okoliša (engl. Good Environmental Status - GES) izdvaja i potiče istraživanja kvalitativnih deskriptora (onečišćujuće tvari, morski otpadak) čime su se istraživanja procjene i unosa plastike, kao najznačajnijeg dijela morskog otpatka, značajno intenzivirala (Bogdanović i sur., 2019., Di Renzo i sur., 2020., Bogdanović i sur., 2021.). Uloženi su značajni napori u cilju prikupljanja podataka i stjecanja znanja o različitim ekološkim i biološkim aspektima MP (Fossi i sur., 2014). Nova saznanja o distribuciji, sastavu i trendovima njezine pojavnostiu različitim organizmima omogućuju definiranje vrsta za daljnja istraživanja toksičnosti, kemijskog prijenosa, biomagnifikacije i bioakumulacije (Lusher, 2013., Rochman i sur., 2015.).

U prvom sustavnom pregledu i metaanalizi znanstvenoistraživačke literature o MP u hrani morskog podrijetla Danopoulos i sur. (2020.) procijenili su sve dostupne studije iz područja kontaminacije morskih ekosustava, s posebnim naglaskom na uzorke komercijalno značajne hrane morskog podrijetla te primjenu validirane analitičke metode za identifikaciju kemijskog sastava MP. Autori su utvrdili da je broj čestica ukupne MP (rezultati se obično izražavaju kao ukupna MP po jedinici mase uzorka ili po jedinici pojedinačnog organizma) u rasponu od 0,1 - 8,6 ukupne MP/g u rakova, 1 ukupne $\mathrm{MP} / \mathrm{g} u$ ježincima (Echinodermata), $0-2,9$ ukupne $\mathrm{MP} / \mathrm{g}$ u ribama i 0 - 10,5 ukupne $\mathrm{MP} / \mathrm{g}$ u mekušcima. Analiza dostupnih rezultata o mekušcima, pri kojoj je izostavljena celuloza, ukazuje kako su redom najrasprostranjeniji polimeri PE i PP. Kada su rezultati istraživanja mekušaca uključivali celofan $(\mathrm{CP})$, onda je upravo to bio najzastupljeniji polimer, a u opadajućem nizu PET, rajon (umjetna svila) i poliester. Kemijskom analizom polimernog sastava na uzorcima rakova utvrđeno je kako su najzastupljeniji polimeri PE i PA (najlon), a slijedili su ih PP i PET. Polimerni profil uzoraka riba $\mathrm{u}$ opadajućem nizu karakteriziraju PE, PP, PET i CP. PE i PP koji su ujedno i najdominantniji identificirani polimeri istraženih morskih organizama, što je u skladu s trendom proizvodnje polimernih materijala (Plastics Europe, 2019.).

Geografska distribucija čestica MP ukazuje na najčešću kontaminaciju mekušaca s obala Azije. Međutim, prethodnu tvrdnju treba uzeti s oprezom budući da je najveći broj istraživanja koji su udovoljavali kriterijima procjene studije Danopoulos i sur. (2020.) iz obalnog dijela Azije. Potrebno je istaknuti i da su istraživanja o ekološkoj zastupljenosti čestica MP često vrlo suprotna. No poznato je da na njezinu raspodjelu $\mathrm{u}$ morskom ekosustavu $\mathrm{u}$ velikoj mjeri utječu geografski čimbenici. Ujedno, na onečišćenje organizama utječe stupanj onečišćenja njihovog okoliša, a slijede ih prehrambene navike i fiziologija. U istraživanju Burns i Boxal 
(2018.) potvrđena je veća kontaminacija česticama MP u blizini urbanih i obalnih područja, dok su Cozar i sur. (2014.) i Avio i sur. (2017.) izvijestili o većim koncentracijama MP i plastike u blizini otvorenog mora i oceanima. Svakako, nužno su potrebna daljnja istraživanja o zemljopisnom obrascu onečišćenja MP.

\section{Procjena izloženosti MP u ljudi}

Opsežna uporaba polimernih materijala rezultirala je prisutnošću MP $u$ prehrambenom lancu i izloženosti potrošača. Njezina pojavnost utvrđena je u zraku, vodi, hrani morskog podrijetla (uključujući školjke), šećeru, medu i pivu (Karbalaei i sur., 2018.). Istraživanje ljudskog izmeta pokazalo je prisutnost prosječno 20 čestica MP u $10 \mathrm{~g}$ materijala kod osam ljudi iz osam zemalja (Schwabl i sur., 2018.). Stoga je važno prikupiti i procijeniti podatke o izloženosti ovom kontaminantu i mogućim učincima na zdravlje ljudi. Pojavnost MP u hrani većinom se odnosi na hranu iz morskog okoliša (EFSA, 2016., Karbalaei i sur., 2018., Hantoro i sur., 2019.). Školjke i manje ribe (inćuni, girice i srdele), budući da se konzumiraju cjelovito, zajedno s probavnim sustavom u kojem je utvrđena najveća prisutnost $\mathrm{MP}$, najviše doprinose izloženosti. Prepreke u procjeni izloženosti su nedostatak standardizirane definicije ovog kontaminanta koja bi sadržavala detalje o veličini, obliku i sastavu čestica te nepostojanje standardiziranih metoda detekcije i identifikacije. Temeljem 20 čestica MP utvrđenih u 10 g ljudskog izmeta i prosječne dnevne količine od 128 g izmeta po osobi (Rose i sur., 2015.), procijenjena je godišnja produkcija/ ispuštanje čestica veće od 90000 čestica MP po osobi.

Pitanje mogućih rizika za sigurnost hrane, povezano s mogućnošću migracije onečišćujućih tvari u jestive dijelove mor- skih životinja i učinkom plastičnih čestica na zdravlje životinja i ekosustave, prvi je puta istaknuto unutar mreže rizika u nastajanju Europske agencije za hranu (EFSA) 2013. godine. Da bi se mogla provesti sveobuhvatna procjena rizika koju lanci mikro i nano plastike predstavljaju za ljudsko zdravlje putem hrane morskog podrijetla, Odbor za kontaminante EFSAe donio je preporuke u vezi s analitičkim metodama, procjenom izloženosti te identifikacijom i karakteriziranjem opasnosti. Potrebno je i bolje razumijevanje moguće kontaminacije hrane kao posljedica postupaka prerade, distribucije i pakiranja hrane. Ispitivanje analize izvora kontaminacije MP u hrani i hrani za životinje primjenom pouzdanih analitičkih metoda trebalo bi osigurati više podataka o njezinoj pojavnosti, osobito za čestice manje od $150 \mu \mathrm{m}$.

Izloženost ljudi mikroplastici putem hrane može se procijeniti pomoću jednostavne jednadžbe izloženosti prema kojoj se prosječan dnevni unos (eng. tolerable daily intake, TDI, broj ili masa čestica po kilogramu po danu) izražava kao omjer sume umnoška masene koncentracije MP u uzorku C, frekvencije izloženosti - EFi, i stope unosa namirnice -IRi i tjelesne mase osobe -BV. Parametri izloženosti, IRi i EFi su dostupni iz nacionalnih baza o prehrambenim navikama. Obrada i kuhanje koji prethode konzumaciji hrane mogu značajno umanjiti ili povećati koncentracije mikroplastike (Birnstiel i sur., 2019., Rist i sur., 2019). Stoga je u cilju smanjivanja ljudske izloženosti MP putem hrane bitna primjena različitih analiza $\mathrm{u}$ sastojcima i finalnom prehrambenom proizvodu. Treba istaknuti da je izražavanje koncentracije MP u hrani (Ci) vrlo kompleksno. Manje čestice i čestice tipa vlakana često se smatraju opasnijim od većih čestica i čestica tipa fragmenata (Kögel i sur., 2020., Yong i sur., 2020.), a MP nano veličine može prijeći barijere u probavnom sustavu (Magri i sur., 
2018.). Treba istaknuti i druge izvore ljudske izloženosti ovom kontaminantu, primjerice putem udisanja mikrovlakana (Vianello i sur., 2019.). Studija izloženosti ljudi MP putem zraka u zatvorenim prostorima pokazala je da je $u$ prosjeku samo $4 \%$ identificiranih čestica bilo podrijetlom od sintetičkih fragmenata i vlakana (Vianello i sur., 2019.). Potencijalni problemi MP u ljudi ovise o načinu izloženosti te je stoga doprinos potrošnje hrane ukupnoj izloženosti potrebno razmotriti u kontekstu opsežnog okvira procjene izloženosti.

\section{Regulatorna osnova za MP i izazovi}

$\mathrm{Na}$ razini EU su propisane zakonodavne mjere $u$ zaštiti zdravlja ljudi koje uključuju Direktivu o kvaliteti vode namijenjene za ljudsku potrošnju (DIREKTIVA (EZ) 2020/2184) te zakonodavni okvir za kontaminante $\mathrm{u}$ hrani, koji uz sebe veže Uredbu vijeća (EEZ) br. 315/93 (o utvrđivanju postupaka Zajednice za kontrolu kontaminanata u hrani i Uredbu Komisije 1881/2006 o utvrđivanju najvećih dopuštenih količina (NDK) određenih kontaminanata u hrani. Za MP je putem Direktive 2020/2184 predviđeno usvajanje metodologije za mjerenje $\mathrm{s}$ ciljem njezina uvrštavanja na Mehanizam popisa za praćenje (rok 12.01.2022.), budući da pripada skupini novih spojeva koji izazivaju sve veću zabrinutost javnosti zbog mogućih štetnih učinaka na zdravlje ljudi. Nadalje, do 12.01.2029. predviđeno je podnošenje Izvješća Europskom parlamentu i vijeću o potencijalnoj ugroženosti izvora vode namijenjene za ljudsku potrošnju zbog prisutnosti MP. Uredba vijeća (EEZ) br. 315/93 za hranu, koja sadržava kontaminante $u$ neprihvatljivim količinama prema mjerilima javnog zdravlja, a posebno u toksičnoj količini, propisuje njezinu zabranu stavljanja na tržište. Radi zaštite javnog zdravlja, utvrđuju se najveća dopuštena odstupanja određenih kontaminanta koje regulira Uredba EU 1881/2006. Razine kontaminanata moraju se držati na onoliko niskim razinama koje je razumno moguće postići uz pridržavanje dobre prakse. Međutim, granične vrijednosti, odnosno NDK se mogu ustanoviti tek kada dokazi postanu dostupni, što ukazuje na rizik po ljudsko zdravlje. NDK se utvrđuju na temelju podataka o pojavljivanju prema principu ALARA (engl. As Low As Reasonably Achievable), princip optimizacije primljene doze koji znači da izlaganje kontaminantu prilikom svakodnevnog života mora biti smanjeno na najmanju moguću mjeru koja se može postići, uzimajući u obzir ekonomske troškove takvog smanjenja doze.

Kao odgovor na sve veći utjecaj ljudskih aktivnosti na morski okoliš, različiti istraživački alati za procjenu ekološkog integriteta i zdravstvenog stanja mora implementirani su u zakonske programeširom svijeta. Direktiva 2008/56/ EZ Europskog parlamenta i vijeća o uspostavljanju okvira za djelovanje Zajednice u području politike morskog okoliša (Okvirna direktiva o pomorskoj strategiji), ima za cilj postići dobro stanje okoliša morskih voda u EU do 2020. Za utvrđivanje karakteristika dobrog stanja okoliša u morskoj regiji ili podregiji propisani su kvalitativni deskriptori. Za sigurnost hrane su osobito značajni kvalitativni deskriptor 8 , koji se odnosi na onečišćujuće tvari u ribi i ostaloj hrani morskog podrijetla koje ne smiju prijeći sadržaje utvrđene zakonodavstvom EU ili drugim relevantnim standardima te deskriptor 9 koji se odnosi na svojstva i količine otpadaka u moru koje ne štete obalnom i morskom okolišu.

Zakonodavci i kreatori politika u cijelom svijetu poduzeli su različite radnje za ublažavanje utjecaja MP na okoliš i javno zdravlje, budući da predstavlja jedinstvene izazove $\mathrm{u}$ procjeni rizika $\mathrm{i}$ donošenju odluka zbog iznimne razno- 
likosti sastava netopljivosti, adsorbiranih i namjerno dodanih zagađivača te složene, heterogene pojave u okolišu (Rochman i sur., 2019.). Osim potrebe za međunarodnom suradnjom $u$ rješavanju utjecaja ovog kontaminanta okoliša i hrane, bliska međusektorska suradnja između znanstvenika i zakonodavstva najvažnija je za unaprjeđenje politika i mogućnosti ublažavanja neželjenih utjecaja emisije MP, kao i njezinog smanjenja dostupnih lokalnim i nacionalnim vladama. Ogledni primjer dobre međusektorske suradnje predstavlja država Kalifornija koja je nedavno donijela dva revolucionarna zakona za rješavanje utjecaja MP $\mathrm{u}$ vodi za piće i morskom okolišu, kako bi odgovorila na sve veću zabrinutost javnosti (California Code of Regulations, 2018.).

Procjena rizika tradicionalnim pristupom provodi se usporedbom izlaganja s definiranim pragom opasnosti. Iako tradicionalni zakonodavni okvir, temeljen na procjeni rizika, dobro funkcionira za jednostavne kemijske zagađivače ili relativno jednostavne smjese zagađivača poznatih kemijskih struktura, sastava i bioloških aktivnosti (npr. dioksini i dioksinima slični poliklorirani bifenili, PCB), često je neodgovarajući u rješavanju rizika kod složenijih zagađivača kao što je MP. Unatoč naporima tijekom posljednjeg desetljeća od strane mjerodavnih tijela EU i globalne razine o mogućim rizicima putem izloženosti MP, EFSA (2016.), ECHA (2019.), FAO (2017.), WHO (2019.), još uvijek ostaje nepoznato imaju li čestice MP negativne učinke po zdravlje ljudi. U svrhu poticanja nastanka regulatorne osnove za MP iz područja kontaminanata $u$ hrani tijekom 2020. godine su pokrenuti znanstveni projekti na temu „Mikro- i nanoplastika u našem okolišu: Razumijevanje izloženosti i utjecaja na ljudsko zdravlje“ u sklopu poziva „Bolje zdravlje i njega, gospodarski rast i održivi zdravstveni sustavi" u okviru Horizon 2020 Work Programme 2018-2020.

\section{Zaključci}

U bližoj budućnosti neophodno je jasno definirati pojam mikro i nano plastike te uspostaviti standardizirane analitičke metode za karakterizaciju i kvantifikaciju ovih kontaminanata $\mathrm{u}$ različitim vrstama hrane. Postupci izolacije MP iz biološkog materijala su često dugotrajni i skupi pa se zahtjev $\mathrm{u}$ iznalaženju jednostavnih postupaka razgradnje ovih tvari nameće kao prioritet. Uzimajući u obzir veliko značenje razvoja ovog područja, nije cilj detektirati sve moguće polimere mikroplastike te potencijalno prisutne aditive i onečišćujuće tvari, već najučestalije i okolišno najzastupljenije sastavnice ovog kontaminanta. Nadalje, procjena prehrambene izloženosti neophodna je za sveobuhvatnu procjenu rizika. Identifikacija i karakterizacija opasnosti - podatci o sudbini (ADME; apsorpcija, distribucija, metabolizam i izlučivanje) i biološkom djelovanju mikro i nano plastike nakon oralne izloženosti, nužne su za što skoriju identifikaciju i karakterizaciju mogućih štetnih učinaka ovih tvari na ljudsko zdravlje putem hrane.

\section{Literatura}

1. AKOUESON, F., L. M. SHELDON, E. DANOPOULOS, S. MORRIS, J. HOTTEN, E. CHAPMAN, J. LI and J. M. ROTCHELL (2020): A preliminary analysis of microplastics in edible versus non-edible tissues from seafood samples. Environ. Pollut. 263, 114452. 10.1016/j. envpol.2020.114452

2. AVIO, C. G., S. GORBI and F. REGOLI (2017): Plastics and microplasticsin the oceans: from emerging pollutants to emerged threat. Mar. Environ. Res. 128, 2-11, PM:D: 27233958. 10.1016/j. marenvres.2016.05.012

3. BAJT, O. (2021): From Plastics to Microplastics and Organisms. FEBS Open. Bio. 11 954-966. 10.1002/2211-5463.13120

4. BIRNSTIEL, S., A. SOARES-GOMES and B. A. P. DA GAMA (2019): Depuration reduces microplastic content in wild and farmed mussels. Mar. Pollut. Bull. 140, 241-247. 10.1016/j.marpolbul.2019.01.044

5. BITENCOURT, G. R., P. A. MELLO, E. M. M. FLORES, C. PIROLA, D. CARNAROGLIO and C. 
BIZZI (2020): Determination of microplastic content in seafood: An integrated approach combined with the determination of elemental contaminants. Sci. Total Environ. 749, 143201. 10.1016/j. scitotenv.2020.142301

6. BOGDANOVIĆ, T., J. PLEADIN, S. PETRIČEVIĆ, E. LISTEŠ, D. SOKOLIĆ, K. MARKOVIĆ, F. OZOGUL and V. ŠIMAT (2019): The occurrence of polycyclic aromatic hydrocarbons in fish and meat products of Croatia and dietary exposure. J. Food Compos. Anal. 75, 49-60. 10.1016/j.jfca.2018.09.017

7. BOGDANOVIĆ, T., L. DI RENZO, D. SOKOLIĆ, G. MASCILONGO, M. BRKLJAČA, F. CITO, P. CALISTRI, V. NOTARSTEFANO, G. GIOACCHINI, E. GIORGINI, C. GIANSANTE, M. BERTI, S. PETRIČEVIĆ, N. FERRI, E. LISTEŠ and F. DI GIACINTO (2021): Microplastics and Bisphenol A in Mussels along Italian and Croatian Coast of the Adriatic Sea. In Session 2: Developments in exposure of humans to micro- and nanoplastics. In: Book of abstracts of the EFSA colloquium 2021 Micro and nanoplastics in food. 6-7 May 2021 Online event.

8. BOTTERELL, Z. L. R., N. BEAUMONT, T. DORRINGTON, M. STEINKE, R. C. THOMPSON and P. K. LINDEQUE (2019): Bioavailability and effects of microplastics on marine zooplankton: A review. Environ. Pollut. 245, 98-110. 10.1016/j. envpol.2018.10.065

9. BURNS, E. E. and A. B. A. BOXAL (2018): Microplastics in the aquatic environment: evidence for or against adverse impacts and major knowledge gaps. Environ. Toxicol. Chem. 37, 27762796. 10.1002/etc. 4268

10. CALIFORNIA CODE OF REGULATIONS (2018): Microplastics Materials. Sect. 1 https://leginfo. legislature.ca.gov/faces/billTextClient.xhtml?bill_ id=201720180SB1263.

11. CATARINO, A. I., V. MACCHIA, W. G. SANDERSON, R. C. THOMPSON and T. B. HENRY (2018): Low levels of microplastics (MP) in wild mussels indicate that MP ingestion by humans is minimal compared to exposure via household fibres fallout during a meal. Environ. Pollut. 237, 675-684. 10.1016/j.envpol.2018.02.069

12. CAU, A., C. G. AVIO, C. DESSĚ, M. C. FOLLESA, D. MOCCIA, F. REGOLI and A. PUSCEDDU (2019): Microplastics in the crustaceans Nephrops norvegicus and Aristeus antennatus: Flagship species for deep-sea environments? Environ. Pollut. 255, 113107. 10.1016/j.envpol.2019.113107

13. CÓZAR, A, F. ECHEVARRIA, J. I. GONZÁLESGORDIO, X. IRIGOIEN, B. UBEDA, S. HERNÁNDEZLÉON, A. T. PALMA, S. NAVARRO, J. GARCÍA-DELOMAS, A. RUIZ, M. L. FERNÁNDEZ-DE-PUELLES and C. M. DUARTE (2014): Plastic debris in the open ocean. Proc. Nati. Acad. Sci. USA 111, 1023910244.10.1073/pnas.1314705111

14. DAWSON, A. L., M. F.M. SANTANA, M. E. MILLER and F. J. KROON (2021): Relevance and reliability of evidence for microplastic contamination in seafood:
A critical review using Australian consumption patterns as a case study. Environ. Pollut. 276-116684 10.1016/j.envpol.2021.116684

15. DANOPOULOS, E., L. C. JENNER, M. TWIDDY and M. ROTCHELL (2020): Microplastic Contamination of Seafood Intended for Human Consumption A Systemic Review and Meta-Analysis. Environ. Health Perspect. 128, 1-32. 10.1289/EHP7171

16. DEHAUT, A., L. HERMABESSIERE and G. DUFLO (2019): Current frontiers and recommendations for the study of microplastics in seafood. Trends Analyt. Chem. 116, 346-359. 10.1016/j.trac.2018.11.011

17. DIREKTIVA (EZ) br. 56/2008 EUROPSKOG PARLAMENTA I VIJEĆA od 17 lipnja 2008 o uspostavljanju okvira za djelovanje Zajednice u području politike morskog okoliša (Okvirna direktiva o pomorskoj strategiji) (Marine Strategy Framework Directive).

18. DIREKTIVA (EU) 2020/2184 EUROPSKOG PARLAMENTA I VIJEĆA od 16 . prosinca 2020.o kvaliteti vode namijenjene za ljudsku potrošnju.

19. DI RENZO, L., G. MASCILONGO, M. BERTI et al. (2021): Potential Impact of Microplastics and Additives on the Health Status of Loggerhead Turtles (Caretta caretta) Stranded Along the Central Adriatic Coast. Water, Air, \& Soil Pollution, 232, 1-20. 10.1007/s11270-021-04994-8

20. DÜMICHEN, E., P. EISENTRAUT, C. G. BANNICK, A. K. BARTHEL, R. SENZ and U. BRAUN (2017): Fast Identification of Microplastics in Complex Environmental Samples by a Thermal Degradation Method. Chemosphere. 174, 572-584. 10.1016/j. chemosphere.2017.02.010

21. ECHA (European Chemical Agency) (2019): Annex XV Restriction Report Proposal for a Restriction for intentionally added microplastics. https:/echa. europa.eu/documents/10162/05bd96e3b969-0a7cc6d0-441182893720.

22. EFSA (European and Food Safety and Authority) (2016): Presence of microplastics and nanoplastics in food, with particular focus on seafood. EFSA Journal 2016;14, e04501.

23. FANG, C., R. ZHENG, H. CHEN, F. HONG, L. LIN, H. LIN, H. GUO, C. BAILEY, H. SEGNER, J. MU and J. BO (2019): Comparison of microplastic contamination in fish and bivalves from two major cities in Fujian province, China and the implications for human health. Aquaculture 512, 734322. 10.1016/j.aquaculture.2019.734322

24. FAO (Food and Agriculture Organization) (2017): Microplastics in fisheries and aquaculture: status of knowledge on their occurrence and implications for aquatic organisms and food safety. Lusher, A. L.; Hollman, P. C. H.; Mendoza-Hill, J. J. FAO Fisheries and Aquaculture Technical Paper. No. 615. Rome, Italy www.fao.org/3/a-i7677e.pdf

25. FOSSI, M. C., D. COPPOLA, M. BAINI, M. GIANNETTI, C. GUERRANTI, L. MARSILI, C. PANTIDE, E. SABATA and S. CLO (2014): Large filter feeding marine organisms as indicators 
of microplastic in the pelagic environment: the case studies of the Mediterranean basking shark (Cetorhinus maximus) and fin whale (Balaenoptera physalus). Mar. Environ. Res. 100, 17-24. 10.1016/j. marenvres.2014.02.002

26. GESAMP (2015): Source, fate and effects of microplastic in the marine environment: a global assessment, In: Kershaw, P. J. (Eds.), IMO/FAO/ UNESOIOC/UNIDO/WMO/IAEA/UN/UNEP/ UNDP Joint Group of Experts on the Scientific Aspects of Marine Environmental Protection), Rep. Study GESAMP No. 90, 96.

27. GESAMP (2019): Guidelines for the monitoring and assessment of plastic litter and microplastics in the ocean. In: Kershaw, P. J., Turra, A., Galgani, F. (Eds.), IMO/FAO/UNESO-IOC/UNIDO/ WMO/IAEA/UN/UNEP/UNDP/ISA Joint Group of Experts on the Scientific Aspects of Marine Environmental Protection), Rep. Stud. GESAMP No. 99, 8-12.

28. HANTORO, I., A. J. LOHR, F. VAN BELLEGHEM, B. WIDIANARKO and A. M. J. RAGAS (2019): Microplastics in coastal areas and seafood: Implications for food safety. Food Addit Contam A Chem. Anal. Control Expo. Risk Assess 36, 674-711. 10.1080/19440049.2019.1585581

29. HEGEDUŠIĆ, A. (2019): Problematika mikroplastike u moru i površinskim vodotocima. Završni rad, Geotehnički fakultet, Sveučilište u Zagrebu.

30. HERMABESSIERE, L. C. HIMBER, B. BORICAUD, M. KAZOUR, R. AMARA, A. L. CASSONE, M. LAURENTIE, I. PAUL-PONT, P. SOUDANT, A. DEHAUT and G. DUFLOS (2018): Optimization, performance, and application of a pyrolysis-GC/MS method for the identification of microplastics. Anal. Bioanal. Chem. 410, 6663-6676. 10.1007/s00216-018-1279-0

31. JAABEN, K., L. SU, J. LI, D. YANG, C. TONG and J. MU (2017): Microplastics and mesoplastics in fish from coastal andfresh waters of China. Environ. Pollut. 221, 141-149. 10.1016/j.envpol.2016.11.055

32. KARAMI, A., A. GOLIESKARDI, C. K. CHOO, N. ROMANO, Y. B. HO and B. SALAMATINIA (2017): A high-performance protocol for extraction of microplastics in fish. Sci. Total. Environ. 578, 485494. 10.1016/j.scitotenv.2016.10.213

33. KARBALAEI, S., P. HANACHI, T. R. WALKER and M. COLE (2018): Occurrence, sources, human health impacts and mitigation of microplastic pollution. Environ. Sci. Pollut. Res. Int. 25, 3604636063. 10.1007/s11356-018-3508-7

34. KIM, J. S., H. J. LEE, S. K. KIM and H. J. KIM (2018): Global pattern of microplastics (MPs) in commercial food-grade salts: Sea salt as an indicator of seawater MP pollution. Environ. Sci. Technol. 52, 1281912828. 10.1021/acs.est. 8 b04180

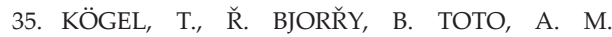
BIENFAIT and M. SANDEN (2020): Micro-and nanoplastic toxicity on aquatic life: Determining factors. Sci. Total Environ. 709, 136050. 10.1016/j. scitotenv.2019.136050
36. KWON, J. H., J. W. KIM, T. D. PHAM, A. TARAFDAR, S. HONG, S. H. CHUN, S. H. LEE, D. Y. KANG, S. B. KIM and J. JUNG (2020): Microplastics in Food: A Review on Analytical Methods and Challenges. Int. J. Environ. Res. Public Health 17, 6710. 10.3390/ijerph17186710

37. LENG, Z, R. K. PADHAN and A. SREERAM (2018): Production of a sustainable paving material through chemical recycling of waste PET into crumb rubber modified asphalt. J. Clean. Prod. 180, 682-688. 10.1016/j.jclepro.2018.01.171

38. LI, J., C. GREEN, A. REYNOLDS, H. SHI and J. M. ROTCHELL (2018): Microplastics in mussels sampled from coastal waters and supermarkets in the United Kingdom. Environ. Pollut. 241, 35-44. 10.1016/j.envpol.2018.05.038

39. LUSHER, A. L., M. MCHUGH and R. C. THOMPSON (2013): Occurrence of microplastics in the gastrointestinal tract of pelagic and demersal fish from the English Channel. Mar. Pollut. Bull. 67, 94-99. 10.1016/j.marpolbul.2012.11.028

40. MAGRI, D., P. SÁNCHEZ-MORENO, G. CAPUTO, F. GATTO, M. VERONESI, G. BARDI, T. CATELANI, D. GUARNIERI, A. ATHANASSIOU, P. P. POMPA and D. FRAGOULI (2018): Laser ablation as a versatile tool to mimic polyethylene terephthalate nanoplastic pollutants: Characterization and toxicology assessment. ACS Nano 12, 7690-7700. 10.1021/acsnano.8b01331

41. MERCOGLIANO, R., C. G. AVIO, F. REGOLI, A. ANASTASIO, G. COLAVITA and S. SANTONICOLA (2020): Occurrence of Microplastics in Commercial Seafood under the Perspective of the Human Food Chain. A Review. J. Agr. Food Chem. 68, 5296-5301. 10.1021/acs. jafc.0c01209

42. NGUYEN, B., D. CLAVEAU-MALLET, L. M. HERNANDEZ, E. G. XU, J. M. FARNER and N. TUFENKJI (2019): Separation and analysis of microplastics and nanoplastics in complex environmental samples. Acc. Chem. Res. 52, 858866. 10.1021/acs.accounts.8b00602

43. QIAO, R., Y. DENG, S. ZHANG, M. B. WOLOSKER, Q. ZHU, H. REN and Y. ZHANG (2019): Accumulation of different shapes of microplastics initiates intestinal injury and gut microbiota dysbiosis in the gut of zebrafish. Chemosphere 236, 124334. 10.1016/j.chemosphere.2019.07.065

44. PLASTICS EUROPE Plastics-the Facts (2019): An Analysis of European Plastics Production, Demand and Waste Data. https://www.plasticseurope.org/ application/files/1115/7236/4388/FINAL_web_ version_Plastics_the_facts2019_14102019.pdf

45. PHUONG, N. N., L. POIRIER, Q. T. PHAM, F. LAGARDE and A. ZALOUK-VERGNOUX (2018): Factors influencing the microplastic contamination of bivalves from the French Atlantic coast: Location, season and/or mode of life? Mar. Pollut. Bull. 129, 664-674. 10.1016/j.marpolbul.2017.10.054

46. RAAMSDONK, L. W. D., M. VAN DER ZANDE, A. A. KOELMANS, L. A. P. HOOGENBOOMR, R. J. B. PETERS, M. J. GROOT, A. A. C. M. PEIJNEBURG 
and Y. J. A. WEESEPOEL (2020): Current Insights into Monitoring, Bioaccumulation and Potential Health Effects of Microplastics Present in the Food Chain. Foods. 9, 72. 10.3390/foods9010072

47. RENZI, M., E. GRAZIOLI, E. BERTACCHINI and A. BLAŠKOVIĆ (2019): Microparticles in table salts: Levels and chemical composition of the smallest dimensional fraction. J. Mar. Sci. Eng. 7, 310. 10.3390/jmse7090310

48. RIBEIRO, F., E. D. OKOFFO, J. W. O'BRIEN, S. FRAISSINET-TACHET, S. O'BRIEN, M. GALLEN, S. SAMANIPOUR, S. KASERZON, J. F. MUELLER, T. GALLOWAY and K. V. THOMAS (2020): Quantitative analysis of selected plastics in highcommercial-value Australian seafood by pyrolysis Gas chromatography mass spectrometry. Environ. Sci. Technol. 54, 9408e9417. 10.1021/acs.est.0c02337

49. RIST, S., I. M. STEENSGAARD, O. GUVEN, T. G. NIELSEN, L. H. JENSEN, L. F. MŘLLER and N. B HARTMANN (2019): The fate of microplastics during uptake and depuration phases in a blue mussel exposure system. Environ. Toxicol. Chem. 38, 99-105. 10.1002/etc.4285

50. ROCHMAN, C. M., A. TAHIR, S. L. WILLIAMS, D. V. BAXA, R. LAM, J. T. MILLER, F .C. TEH, S. WERORILANGI and S. J. TEH (2015): Anthropogenic debris in seafood: Plastic debris and fibers from textiles in fish and bivalves sold for human consumption. Sci. Rep. 5, 14340. 10.1038/ srep 14340

51. ROCHMAN, C. M., C. BROOKSON, J. BIKKER et al. (2019): Rethinking microplastics as a diverse contaminant suite. Environ. Toxicol. Chem. 38, 703711. 10.1002/etc. 4371

52. ROSE, C., A. PARKER, B. JEERSON and E. CARTMELL (2015): The Characterization of Feces and Urine: A Review of the Literature to Inform Advanced Treatment Technology. Crit. Rev. Environ. Sci. Technol. 45, 1827-1879. 10.1080/10643389.2014.1000761

53. SCHWABL, P., S. KOPPEL, P. KONIGSHOFER, T. BUCSICS, M. TRAUNER, T. REIBERGER and B. LIEBMANN (2019): Detection of Various Microplastics in Human Stool: A Prospective Case. Ann. Intern. Med. 171, 453-457. 10.7326/M19-0618
54. SMITH, M., D. C. LOVE, C. M. ROCHMAN and R. A. NEFF (2018): Microplastics in seafood and the implications for human health. Curr. Environ. Heal Reports 5, 375-386. 10.1007/s40572-018-0206-Z

55. SILVA, A. B., A. S. BASTOS, C. I. L. JUSTINO, J. P. DA COSTA, A. C. DUARTE and T. A. P. ROCHA-SANTOS (2018): Microplastics in the Environment: Challenges in Analytical Chemistry - A Review. Anal. Chim. Acta 1017, 1-19. 10.1016/j. aca.2018.02.043

56. SÜSSMANN, J., T. KRAUSE, D. MARTIN, E. WALZ, R. GREINER and S. ROHN (2021): Evaluation and optimisation of sample preparation protocols suitable for the analysis of plastic particles present in seafood. Food Control 125, 107969. 10.1016/j. foodcont.2021.107969

57. UREDBA VIJEĆA (EEZ) br. 315/93 od 8. veljače 1993. o utvrđivanju postupaka Zajednice za kontrolu kontaminanata u hrani.

58. UREDBA KOMISIJE (EZ) br. 1881/2006 od 19. prosinca 2006. o utvrđivanju najvećih dopuštenih količina određenih kontaminanata u hrani.

59. VALLERO, D. A. (2016): Environmental Biochemodynamic Processes. Environmental Biotechnology. Elsevier, pp. 89-150. 10.1016/B978-012-407776-8.00003-7

60. VIANELLO, A., R. L. JENSEN, L. LIU and J. VOLLERTSEN (2019): Simulating human exposure to indoor airborne microplastics using a Breathing Thermal Manikin. Sci. Rep. 9, 8670. 10.1038/s41598019-45054-w

61. YONG, C. Q. Y.S. VALIYAVEETILL and B. L. TANG (2020): Toxicity of microplastics and nanoplastics in mammalian systems. Int. J. Environ. Res. Public Health 17, 1509. 10.3390/ijerph17051509

62. WADDELL, E. N., N. LASCELLES and J. L. CONKLE (2020): Microplastic contamination in Corpus Christi Bay blue crabs, Callinectes sapidus. Limn. Oceanogr. Lett. 5, 92-102. 10.1002/lol2.10142

63. WHO (World Health Organization) (2019): Microplastics in drinking-water. Available at: https://www.who.int/water_sanitation_health/ publications/microplastics-in-drinking-water/en pristupljeno: 07/05/2021. 


\section{Microplastics - a potential risk for seafood safety}

Tanja BOGDANOVIĆ, BSc, PhD, Senior Scientific Associate, Croatian Veterinary Institute, Veterinary Institute Split, Split, Croatia; Jelka PLEADIN, BSc, PhD, Scientific Advisor in Tenure, Full Professor, Croatian Veterinary Institute, Zagreb, Croatia; Sandra PETRIČEVIĆ, BSc, PhD, Postdoctoral Researcher, Croatian Veterinary Institute, Veterinary Institute Split, Split, Croatia; Mia BRKLJAČA, BSc, PhD, CROMARIS d.d., Zadar, Croatia; Irena LISTEŠ, DVM, PhD, Scientific Associate, Eddy LISTEŠ, DVM, PhD, Scientific Advisor, Croatian Veterinary Institute, Veterinary Institute Split, Split, Croatia

Microplastics (MPs) are recognized as a multifaceted stressor based on their physical effects due to particle size, shape, and concentration, and chemical effects ensuing from the use of hazardous chemicals. Evidence of the presence of MPs in food are increasing, and the number of publications on MPs in seafood has increased at an exponential rate in recent years. However analytical detection methods of MPs in seafood are limited even despite the available techniques that enable MP separation and size determination. The analytical detection of MPs requires obtaining information on both the chemical composition and the morphological structure of particles. No single technique is able to chemically and morphologically identify MPs, though a broad range of complementary analytical methodologies have been applied in the detection and identification of MPs. MPs can cause biological, chemical and physical health effects. In order to assess whether the uptake of MPs via seafood can pose a risk to human health, exposure must first be quantified and then it can be determined whether this exposure is high enough to have a detrimental effect. Human exposure to MP contained in food has become a significant concern owing to the increasing accumulation of microplastics in the environment. This paper provides an overview of the existing research on MP presence in seafood, including analytical methods for microplastic separation, and instrumental determination of concentration, shapes, and material types in complex biological material. Regulatory requirements and challenges to support fit-for-purpose research activities on this contaminant are summarized, and information provided for possible regulation on MPs in food.

Key words: microplastics; seafood; occurrence; exposure assessment 